\title{
Streptococcus pneumoniae Serotype 15B IgG Antibody Measurement
}

National Cancer Institute

\section{Source}

National Cancer Institute. Streptococcus pneumoniae Serotype 15B Ig G Antibody

Measurement. NCI Thesaurus. Code C142263.

The determination of the amount of Streptococcus pneumoniae serotype 15B Ig G antibody present in a sample. 